\title{
A Reconnaissance of a Channel Dam Site and Flood Area on the San Saba River, Menard County, Texas
}

Joseph H. Labadie

Follow this and additional works at: https://scholarworks.sfasu.edu/ita

Part of the American Material Culture Commons, Archaeological Anthropology Commons, Environmental Studies Commons, Other American Studies Commons, Other Arts and Humanities Commons, Other History of Art, Architecture, and Archaeology Commons, and the United States History Commons

Tell us how this article helped you.

This Article is brought to you for free and open access by the Center for Regional Heritage Research at SFA ScholarWorks. It has been accepted for inclusion in Index of Texas Archaeology: Open Access Gray Literature from the Lone Star State by an authorized editor of SFA ScholarWorks. For more information, please contact cdsscholarworks@sfasu.edu. 
A Reconnaissance of a Channel Dam Site and Flood Area on the San Saba River, Menard County, Texas

\section{Creative Commons License}

\section{(c) (1) (8)}

This work is licensed under a Creative Commons Attribution-NonCommercial 4.0 International License 


\section{A RECONNAISSANCE OF \\ A CHANNEL DAM SITE AND FLOOD AREA \\ ON THE SAN SABA RIVER, MENARD COUNTY, TEXAS}

Joseph H. Labadie

Texas Antiquities Committee Permit No. 461

Thomas R. Hester, Principal Investigator

Center for Archaeological Research The University of Texas at San Antonio ${ }^{\circ}$ Archaeological Survey Report, No. 147 
The following information is provided in accordance with General Rules of Practice and Procedure Chapter 41.11 (Investigation Reports), Texas Antiquities Committee:

1. Type of investigation: Pedestrian reconnaissance of a portion of the San Saba River, 1 ocated 0.7 kilometers west of the City of Menard, Texas;

2. Project name: San Saba River Survey;

3. County: Menard County, Texas;

4. Principal Investigator: Thomas R. Hester; Co-Principal Investigator: Jack D. Eaton; Field Director: Joseph H. Labadie;

5. Name and location of sponsoring agency: City of Menard, Texas;

6. Texas Antiquities Committee Permit No. 461;

7. Published by the Center for Archaeological Research. The University of Texas at San Antonio, San Antonio, Texas 78285, 1985 .

A 7 ist of publications offered by the Center for Archaeological Research can be obtained by sending $\$ 1.00$ to the Center for Archaeological Research. The University of Texas at San Antonio, San Antonio, Texas 78285. 
LIST OF FIGURES ..................... i i

LIST OF TABLES ................................

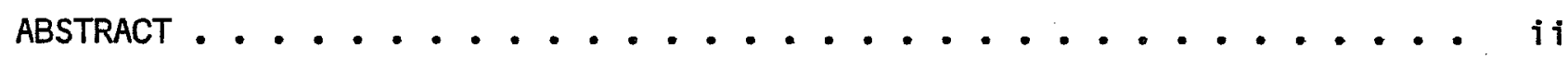

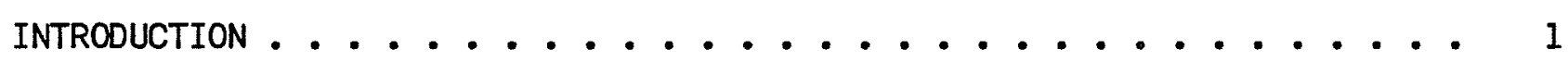

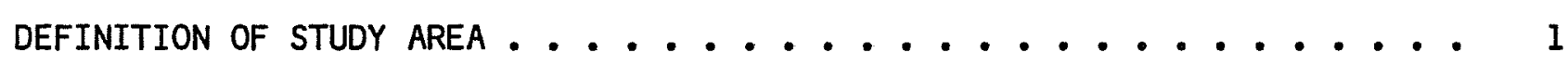

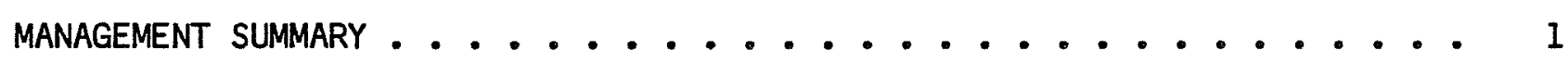

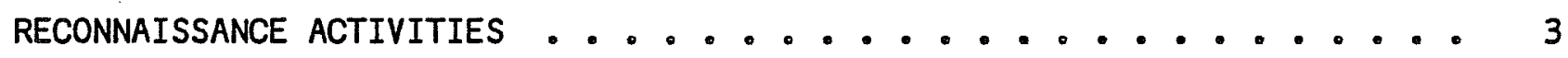

PRESENT CONDITION OF THE PRESIDIO SAN SABA .............. 3

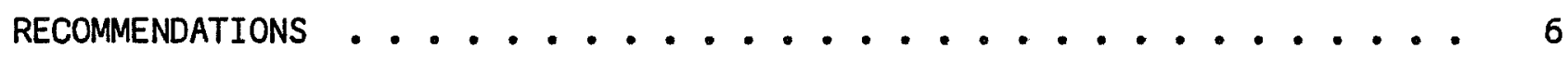

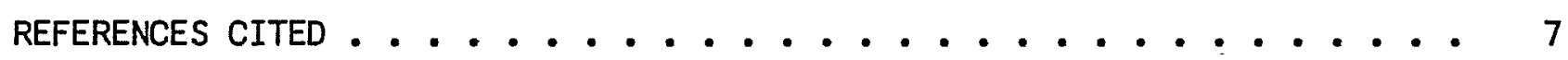

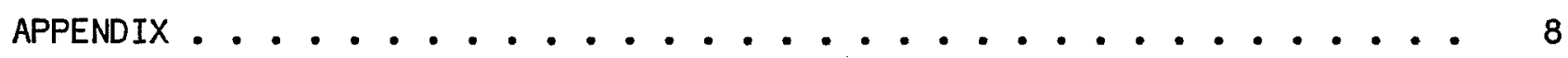

\section{LIST OF FIGURES}

1. Area of Menard, Texas .................. 2

2. Plan Drawing of the Presidio San Saba Indicating the

Approximate Locations of Machine-Excavated Sprinkier System

Trenches Examined by this Reconnaissance ...........

\section{LIST OF TABLES}

1. Historical Peak Annual Floods of the San Saba River at Menard,

Texas .................... 


\section{ABSTRACT}

During December 1984, a reconnaissance was carried out along portions of the San Saba River west of Menard, Texas. The purpose of the study was to examine the location where a new channel dam will be constructed, and areas upstream, including Presidio San Saba (4I MN 1), to determine what cultural resources might be affected by any water level change as a result of dam installation.

The reconnaissance determined that construction of a new concrete dam to replace an earlier earthen dam of similar size will not impact any known cultural resources. The water level is not expected to be appreciably higher and, therefore, will not impact Presidio San Saba.

However, during a visit to Presidio San Sabá, it was noted that golf course sprinkler system trenches have recently been excavated across portions of the historic site by the County of Menard. This trenching has disturbed buried cultural resources. 


\section{INTRODUCTION}

On December 12, 1984, archaeologists from the Center for Archaeological Research. The University of Texas at San Antonio (CAR-UTSA), carried out a reconnaissance of portions of the San Saba River area west of Menard, Texas, including the historic site of Presidio San Saba (41 MN 1; properly, San Luis de 1 as Amarillas; Gilmore 1967).

The purpose of the reconnaissance was to examine the proposed location of a new channel dam and the areas of possible impact by any pool level rise resulting from the dam installation.

The project was done under contract with the City of Menard (Mr. James Cannon, letter dated December 6,1984 ) and was required as part of grant app 7 ication to Farmers Home Administration. The project was reviewed by the Texas Historical Commission (as required by 36 CFR 66 and Section 106 of the National Historic Preservation Act of 1966) and the Texas Antiquities Committee under the specific terms of Antiquities Permit No. 461. Research followed the guidel ines suggested in the "Council of Texas Archeologists Performance Guidelines" (CTA 1981).

The field work was done by Joseph H. Labadie and George H. Deaton, Center staff archaeologists, under the supervision of Dr. Thomas R. Hester, Center Director, and Jack D. Eaton, Associate Director.

\section{DEFINITION OF STUDY AREA}

The area of study was 1 imited to properties owned by the City and County of Menard along a portion of the San Saba River, west of the City of Menard, Texas, including the historic site of Presidio San Saba (Fig. 1). The river banks on both sides of this part of the San Saba River are essentially treeless, with ground cover 1 imited to tall grasses and scattered whitebrush. Undercutting of the river bank by seasonal flooding has created several steep cutbanks, one in the immediate vicinity of the Presidio along the north bank, and one along the south bank near the proposed channel dam site.

The terrain above the river bank on the south side of the river is generally flat for a distance of $0.6 \mathrm{~km}$. The river terrace abruptly ends at the base of a sheer 1 imestone escarpment, which rises nearly 200 feet above the floodplain. Most of the immediate area north of the river has been developed by city and county as a recreational facility and includes two 1 ittle-league basebal 1 diamonds, several unpaved roads, picnic tables, and a nine-hole golf course.

\section{MANAGEMENT SUMMARY}

This survey was requested by the City Administrator for the City of Menard, Mr. James Cannon. The City of Menard is planning the construction of a new concrete channel dam to replace an old earthen dam that was washed-out by recent floodwaters. The dam is needed to pool waters of the San Saba River which are essential to the maintenance of the local water table from which city water wells draw water for the City of Menard. The new dam is of equal 
proportions to the former earthen dam and would be located ca. 50 feet upstream from the old dam which had stood for four years. The City Administrator provided a detailed set of architectural drawings for the proposed channel dam and joined the author in an on-site tour of the areas of potential impact.

\section{RECONNAISSANCE ACTIVITIES}

The major objective of the reconnaissance was to determine the maximum expected pool level to be created behind the dam. For this, we used architectural drawings provided by the City Administrator. Once the area of possible impact was determined, a pedestrian reconnaissance of the Presidio and surrounding river bank area was to be made to see exactly what areas might be impacted by the new water levels (see Figs. 1 and 2). The annual 100-year flood data for the area was used as a basel ine for maximum floodstage of the San Saba River in this vicinity (Table 1 ).

Results of this reconnaissance indicate that the historic site of the Presidio San Sabs will not be directly impacted by the construction of a channel dam in the proposed location. However, once the pool of water behind the dam has stabilized, it may increase the rate of undercutting and sloughing of the cutbank immediately below the site. Although we closely examined the existing cutbanks and found no trace of cultural resources (and thus, no collections were made), we believe that the City of Menard should stabilize the river bank to decrease the rate of undercutting and associated sloughing; the possible use of rip-rap was discussed with the City Administrator of Menard.

During periods of normal flow, water levels behind the dam are expected to rise three to four feet above the present, unchecked water levels; the expected maximum rise would equal the top of the channel dam (1874.7 feet MSL). The site of the Presidio has an approximate surface elevation of 1885.0 feet (MSL) in the vicinity of the south Presidio wal1. A clear separation of more than 11 vertical feet exists between the expected maximum pooled water levels and the Presidio wal1 nearest the river. If water was to inundate the site during seasonal flooding, most of the town of Menard and the surrounding areas would also be underwater. This entire area falls within the 100-year floodplain which roughly corresponds to the 1910 (MSL) contour interval on a USGS topographic map (Fig. I).

\section{PRESENT CONDITION OF THE PRESIDIO SAN SABA}

In the course of the reconnaissance, we had the opportunity to examine the site of Presidio San Saba, 1 ocated in the midst of the Menard County Golf Course (Fig. 2). We offer the following observations which, although outside the project requirements, we feel to be of interest for cultural resource management.

The Presidio, once the most powerful military outpost in Texas during the 1 ate 18th century, is now 1 ittle more than a crumbling ruin (Morfi 1935; Weddle 1964; Gi1more 1967; Moorhead 1975; Ivey 1981; Fox 1983). Partial standing wal1s, reconstructed as part of an attempted restoration during the 1930s, are beginning to coll apse. 
TABLE 1. HISTORICAL PEAK ANNUAL FLOODS OF THE SAN SABA RIVER AT MENARD, TEXAS (Data Provided by the City of Menard)

\begin{tabular}{llr} 
Date & $\begin{array}{l}\text { Stage } \\
(\text { feet }\end{array}$ & $\begin{array}{c}\text { Discharge } \\
\text { (cubic feet per second) }\end{array}$ \\
\hline 1899 & 23.3 & unknown \\
1938 & 22.2 & 130,000 \\
1936 & 21.3 & 101,000 \\
1980 & 21.0 & 90,500 \\
1946 & 18.9 & 60,000 \\
1974 & 18.9 & 59,200 \\
1931 & 18.7 & 57,200 \\
1942 & 18.2 & 49,200 \\
1956 & 18.1 & 48,000 \\
1922 & 17.8 & 44,000 \\
1930 & 17.7 & 43,400 \\
1957 & 17.5 & 41,000 \\
1978 & 17.1 & 35,400 \\
1958 & 16.7 & 31,900 \\
1932 & 16.7 & 31,300 \\
1943 & 16.6 & 30,800 \\
1954 & 15.2 & 21,100 \\
1977 & 14.7 & 18,900 \\
1935 & 14.6 & 18,100 \\
1962 & 14.5 & 17,900 \\
1934 & 14.5 & 17,600 \\
1960 & 13.9 & 15,000 \\
& & \\
\hline & & \\
\hline
\end{tabular}

Note: 1. This table shows the annual peak flow only.

2. Bank full stage is approximately 14.0 feet.

3. Datum of gage is elevation 1863.05 feet MSL. 


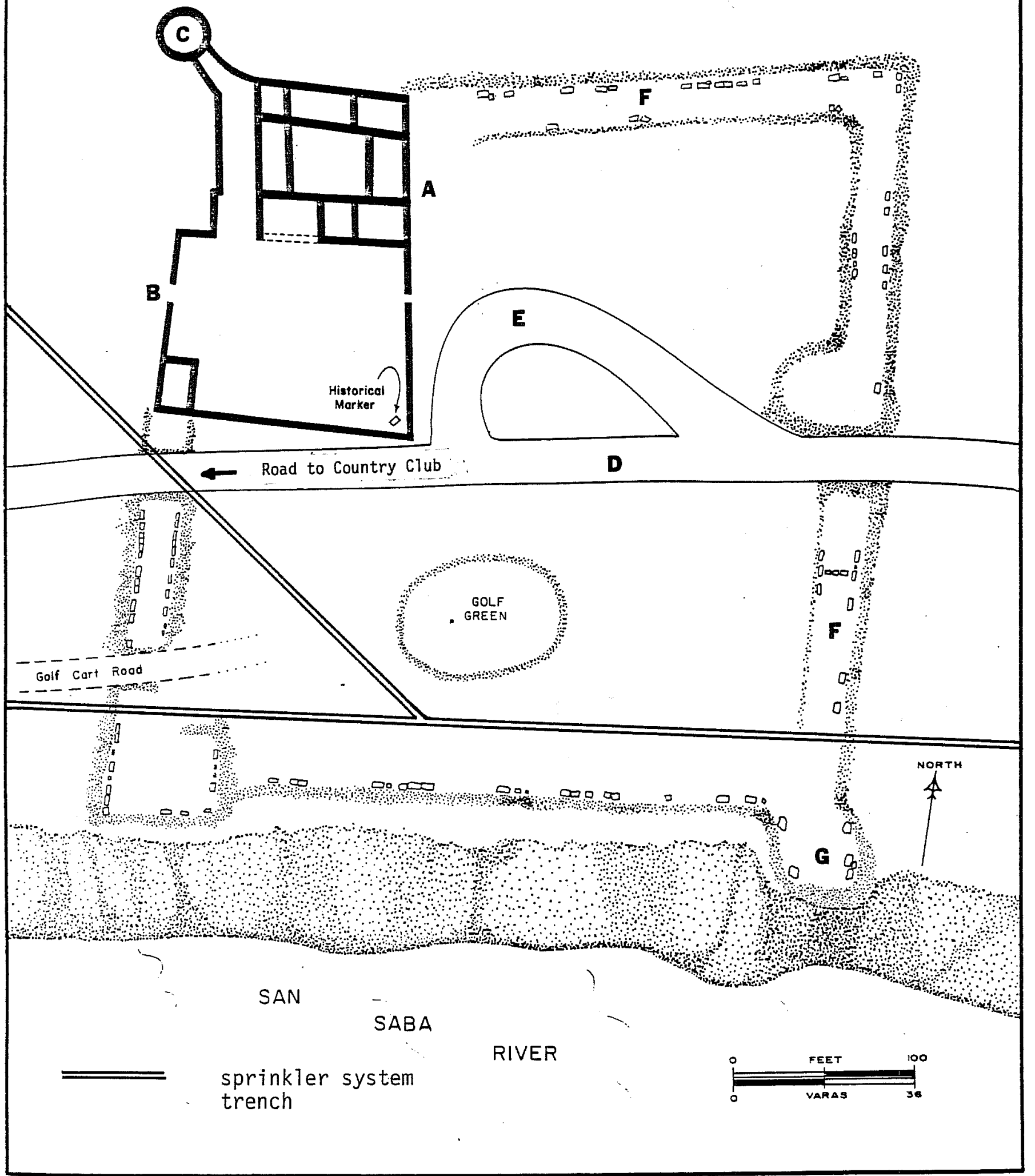

Figure 2. Plan Drawing of the Presidio San Saba Indicating the Approximate Locations of Machine-Excavated Sprinkier System Trenches Examined by this Reconnaissance (map adapted from Ivey 1981:5). The entire area shown here, from the river bank north, was examined by the field team. $A$, walls reconstructed in ca. 1932 by the WPA; $B$, main gate as reconstructed; $C$, northwest bastion as reconstructed; $D$, road to the Menard Country Club; $E$, turnout for visitors to the Presidio; F, mounds of wal1 ruins; G, mound covering southeast bastion. 
The original configuration of the Presidio was roughly square with a main gate located in the west wa11. Today, the site is bisected on its east-west ax is by an unpaved golf course road. Partial standing walls and linear rubble piles are 1 imited to areas north of the golf course road. South of the roads slightly elevated 1 inear features in an otherwise level area denote former wal 1s. A golf green has been constructed right in the middle of what used to be the Presidio's plaza.

The golf course (owned by Menard County) is currently installing an underground sprinkler system to water a 11 nine golf greens. The entire golf course, at present, has a near gridlike series of open trenches $(60 \mathrm{~cm}$ wide $\times 50 \mathrm{~cm}$ deep) that contain one inch and three inch diameter PVA piping; each golf green has been encircled by a trench which contains a one-inch PVA pipe with four sprinkler heads. The raised 1 inear features that denote the location of Presidio walls have been trenched through in three places.

Al 1 of the trenches at the Presidio were walked over, and a selective collection was made from a trench in the area of the southwest wall. This trench, which cut through the buried Presidio wall, revealed a well-defined, gray-ashen lens $30 \mathrm{~cm}$ below the present-day ground surface. The lens $(20 \mathrm{~cm}$ thick $\times 1.2 \mathrm{~m}$ long) is located immediately outside the wall and extends away from the wall. Still visible in the ashen lens were bits of charcoal, small pieces of burned 1 imestone, and several burned mussel she11 fragments. Examination of the backdirt from the trench provided additional materials. In all, a selective collection was made in this area, consisting of 11 pieces of bone (four large $r i b$ bone sections and seven unidentifiable bone fragmentsmall we 11 preserved and not burned), eight unburned mussel shell fragments (one with the umbo stil1 attached), a rusty piece of iron, a modified chert cobble, and a 1 arge, unglazed, sandy paste pottery sherd. Investigation of the other two open trenches and associated backdirt failed to identify any additional cultural materials. A small sherd of Spanish Colonial period majolica and a tertiary chert $f 1$ ake were found on the surface near the Presidio's northeast corner.

\section{RECOMMENDATIONS}

As a result of the reconnaissance, it was determined that the construction of the new dam and predicted water level change will not directly affect Presidio San Saba (4I MN I) or any other known cultural resources.* However, fluctuating water levels in the vicinity of Presidio San Saba might indirectly affect parts of the buried Presidio south wall on the river bank through bank undercutting. We recommend that consideration be given to stabilizing the

* One nearby cultural resource of which we are aware is a Spanish Colonial acequia (Nicolas de Lafora, in Moorhead 1975). According to a map published by Gilmore (1967:Fig. 2A), the acequia is on the south side of the river, some distance from the stream and with its initiation point well upstream from the Presidio area. Anne Fox (personal communication) examined the acequia in 1981 and noted that it is stil1 being used for irrigation. She considers it to be wel1 outside the reconnaissance area and does not believe the types of modification proposed by the City of Menard would endanger this feature. 
eastern bank in that area; we emphasize again that the cutbanks were visually inspected during the reconnaissance, and no prehistoric or historic materials were observed.

We also noted that the machine excavations of sprinkler system trenches across the southern part of Presidio San Saba have impacted the cultural resource, including the partial destruction of at least one midden feature. Since no subsurface study of this area of the Presidio has been undertaken in the past, it should be protected from further impact. Should any future disturbances be planned at Presidio San Saba (a National Register Historic Site and a State Historic Landmark), this should be preceded by a carefully designed project of investigation and documentation to include controlled subsurface excavations.

\section{REFERENCES CITED}

Council of Texas Archeologists (CTA)

1981 Council of Texas Archeologists Performance Guidel ines, Newsletter, Council of Texas Archeologists 5(2).

Fox, D. E.

1983 Traces of Texas History: Archeological Evidence of the Past 450 Years. Corona Publishing Company, San Antonio.

Gilmore, K.

1967 A Documentary and Archeological Investigation of Presidio San Luis de 1 as Amarillas and Mission Santa Cruz de San Saba. Menard County, Texas: A Preliminary Report. State Buflding Commission Archeological Program, Report 9.

Ivey, J. and the CAR Staff

1981 A Reexamination of the Site of Presidio San Saba. La Tierra $8(4): 2-11$.

Moorhead, M. L.

1975 The Presidio: Bastion of the Spanish Borderlands. University of Ok lahoma Press, Norman.

Morfi, Fray J. A.

1935 History of Texas 1673-1779. Parts I and II. The Quivira Society, Albuquerque.

Weddle, R. S.

1964 The San Saba Mission: Spanish Pivot in Texas. University of Texas Press, Austin. 


\section{APPENDIX ${ }^{1}$}

Pau 7 White and I visited Menard on January 30, 1985. Representatives of the county pointed out an apparent feature to us that was approximately 150 feet upstream from the Presidio, in the river channel.

We did not inspect this feature closely, but it was visible from the Presidio's cutbank. The county officials identified the feature as the remains of the original acequia dam, constructed by the Spanish occupants of the Presidio.

What we could see was a plie of cut 7 imestone blocks protruding out of the shallow northern branch of the main stream channel. Regardless of whether it is actually a Spanish feature, it did appear to be a cultural feature. I have checked the maps here at the [Texas Historical] Commission and we have no records of such a feature; but, its location does correspond with the head waters of the acequia that runs along the south bank of the San Saba River. Interestingly enough, the acequia has never been officially recorded either, though it is plotted on some maps.

This stone feature is within the inundation margin of the city's reservoir and was inundated when the 1 ast dam held water. Inundation will probably not have an adverse effect on such a feature.

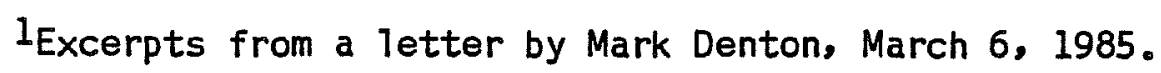



